\title{
CDC73 wt Allele
}

National Cancer Institute

\section{Source}

National Cancer Institute. CDC73 wt Allele. NCI Thesaurus. Code C54289.

Human CDC73 wild-type allele is located in the vicinity of $1 \mathrm{q} 25$ and is approximately 132 $\mathrm{kb}$ in length. This allele, which encodes parafibromin protein, plays a role in the modulation of both RNA polymerase II-directed transcription and histone methylation. Hyperparathyroidism-jaw tumor syndrome is associated with mutations that result in truncation of this gene. 